\section{Aportes das ciências sociais e humanas sobre família e parentesco: contribuições para a Estratégia Saúde da Família}

\author{
The social sciences and \\ humanities on family and \\ kinship: contributions to the \\ Family Health Strategy
}

Michely de Lima Ferreira Vargas $^{i}$

Analista em Educação e Pesquisa em Saúde, Escola de Saúde Pública do Estado de Minas Gerais. Belo Horizonte - MG - Brasil

orcid.org/0000-0003-1367-0831

michely.vargas@esp.mg.gov.br

Recebido em 25 fev. 2019.

Aprovado em 16 jan. 2020.
VARGAS, Michely de Lima Ferreira. Aportes das ciências sociais e humanas sobre família e parentesco: contribuições para a Estratégia Saúde da Família. História, Ciências, Saúde - Manguinhos, Rio de Janeiro, v.28, n.2, abr.-jun. 2021, p.351-374.

Resumo

Reflete-se sobre a temática da família e do parentesco, tendo em vista sua apropriação como norte de políticas públicas na saúde, em especial a Estratégia Saúde da Família. São apresentadas contribuições de estudos clássicos de antropologia, sociologia e história sobre origens, papel social, funções e transformações da família ao longo do tempo, incluindose abordagens de outras questões contemporâneas. Comentam-se análises específicas sobre o Brasil desde a família patriarcal, apresentando-se dados demográficos atuais e finalizando com comentários sobre a necessidade de ampliar, na formação e nas orientações fornecidas aos profissionais da saúde, reflexões mais amplas sobre família tendo em vista fortalecer a implementação de políticas públicas.

Palavras-chave: família; parentesco; ciências sociais e humanas; Estratégia Saúde da Família (ESF).

Abstract

This article discusses contributions from the social and human sciences on the topic of family and kinship, considering the appropriation of the family as central to public health policies, particularly the Family Health Strategy. Contributions from classical anthropological, sociological, and historical research on the origins, social role, functions, and transformations of the family over time are presented, and include approaches related to family, gender, social class, and other contemporary issues. Specific analyses related to Brazil and the patriarchal family, among other aspects, are discussed along with current demographic data, concluding with comments on the need to expand reflections on the family in the training and guidelines provided to health professionals to strengthen the implementation of public policies.

Keywords: family; kinship; social sciences and humanities; Family Health Strategy. 
$\mathrm{O}$ estudo da família e do parentesco, nas ciências humanas e sociais, tem sido uma tradição renovada e atualizada ao longo dos anos. Examinada a partir de perspectivas diversas, a família mobiliza não apenas estudiosos e pesquisadores, mas também juristas e legisladores. Mais recentemente, no Brasil, a família tem se constituído como campo de disputa simbólica entre correntes conservadoras e liberais, que buscam fazer prevalecer suas definições de família, tendo em vista, de um lado, a manutenção de uma concepção hegemônica, fundada na normatividade heterossexual, de preferência com a finalidade da procriação, e, de outro lado, a inclusão, nas definições de família, de outros arranjos, tais como os baseados na conjugalidade e no direito à filiação por parte de casais homoafetivos (Nichnig, 2019). Nesse sentido, o reconhecimento da união estável de casais homoafetivos pelo Supremo Tribunal Federal (STF) em 2011, reafirmado em decisão proferida em 2019, relativa a julgamento sobre a (in)constitucionalidade da lei distrital n.6.160/2018, que estabelecia a Política Pública de Valorização da Família no Distrito Federal (Brasília, 2018) e definia como família somente aquelas constituídas por homem e mulher, além de significar avanços incontestáveis, evidencia que a concepção de família, para além de uma questão semântica, influencia, de forma concreta, o acesso a direitos e deveres, e, assim, o exercício da cidadania. Ser ou não reconhecido como família pode afetar a forma como se é ou não incluído no rol das políticas e programas públicos que disponibilizam algum tipo de proteção e garantias. O que se torna ainda mais relevante quando se constata que a família tem se tornado cada vez mais foco de políticas públicas em diversas áreas e setores, tais como a seguridade social, a educação e a saúde. Como exemplos podem ser citados o Programa Bolsa Família, destinado à transferência direta de renda para famílias em situação de pobreza, e na área da saúde a Estratégia Saúde da Família (ESF).

Criada com a intenção de ampliar o acesso da população ao sistema de saúde, a ESF "apresenta trajetória exemplar" (Souza, 2010, p.31), uma vez que de programa inicialmente focalizado, devido à escassez de recursos quando de sua criação, restrito a municípios que sofriam naquele período com a miséria e a fome, consolidou-se como "estratégia estruturante de uma Política Nacional de Atenção Básica", desempenhando papel essencial no fortalecimento do Sistema Único de Saúde (SUS) (p.31). Ao longo dos anos, a ESF colaborou para reduzir a mortalidade infantil, elevar o número de gestantes que realizam pré-natal desde o início da gravidez, diminuir a quantidade de internações decorrentes de agravos, tais como diarreia, ampliar o atendimento de indivíduos com doenças crônicas, bem como auxiliar o estabelecimento de redes de atenção em regiões do país que não contavam com acesso a serviços de saúde (Souza, 2010).

A ESF se fundamenta nos princípios estruturantes do SUS, ou seja, a universalidade do acesso, a integralidade e a igualdade da assistência, consagrados no artigo 198 da Constituição Federal (Brasil, 1988) e ratificados no artigo 7 da lei n.8.080/1990 (Brasil, 20 set. 1990), sendo suas diretrizes definidas na Política Nacional de Atenção Básica (Pnab). Recentemente, em 2017, foi publicada a portaria n.2.436, que aprovou a nova Pnab, estabelecendo a revisão de diretrizes para a organização desse nível de atenção no SUS (Brasil, 2017). Essa revisão ocorreu em momento conturbado para a política brasileira, no contexto pós-destituição da presidente democraticamente eleita, Dilma Rousseff, e durante a ascensão e recrudescimento de discursos, difundidos em diversos setores institucionais e entre todos os estratos sociais, de 
apoio à diminuição do papel do Estado na promoção e no financiamento de políticas públicas nas áreas de saúde e educação, entre outras. A análise da nova Pnab evidencia a possibilidade de que algumas das alterações propostas ocasionem prejuízos para a população brasileira atendida pela atenção básica em saúde (ABS), especialmente aquela parcela composta por setores das camadas populares, que dependem integralmente dos serviços disponibilizados pelo SUS. Apesar de definir a ESF como "prioritária", a portaria publicada em 2017 faculta a abertura a outros modelos como estratégias organizativas da ABS. A tônica de flexibilização caracteriza outros aspectos da política, podendo afetar negativamente a estrutura e o funcionamento da ESF, a exemplo da possibilidade de diferenciação dos serviços ofertados, caracterizados como "essenciais" ou "ampliados", bem como a indefinição quanto ao número de agentes comunitários de saúde que deverão compor cada equipe de saúde da família. $\mathrm{O}$ escalonamento na amplitude dos serviços pode vir a comprometer a qualidade do cuidado em saúde ofertado na ABS conforme a região do país, reforçando as desigualdades já existentes. Por sua vez, a possibilidade de que o número de agentes comunitários de saúde por equipe seja "definido de acordo com base populacional, critérios demográficos, epidemiológicos e socioeconômicos, de acordo com definição local" (Brasil, 2017) pode pôr em risco o papel estratégico dessa categoria de trabalhadores na consolidação da ESF no país.

Além disso, na Pnab de 2017, diferentemente das versões anteriores, a cobertura de $100 \%$ da população adscrita somente é recomendada no caso de territórios socialmente vulneráveis ou "de grande dispersão territorial" (Brasil, 2017), sendo que, apesar de determinar que a população adscrita por equipe de atenção básica e de saúde da família seja de dois mil a 3.500 pessoas, o documento admite a possibilidade de "outros arranjos de adscrição, conforme vulnerabilidades, riscos e dinâmica comunitária, ... podendo ser maior ou menor do que o parâmetro recomendado, de acordo com as especificidades do território, assegurando-se a qualidade do cuidado" (Brasil, 2017). Essas alterações, na prática, podem vir a ocasionar sobrecarga de trabalho para o agente comunitário de saúde e demais componentes das equipes de saúde da família, ocasionando prejuízos à cobertura da população e à qualidade do cuidado em saúde.

Se a princípio essa flexibilidade pode parecer positiva, por pretensamente contemplar diferentes realidades regionais em um país de dimensões continentais, por outro lado, embute o risco de que os avanços possibilitados pela adoção da ESF venham a se perder e a se diluir. Apesar da necessidade de aprimoramento e da persistência de questões ainda a equacionar, tem sido por meio da $\mathrm{ABS}$ que os princípios do SUS encontraram sua expressão mais consistente. Ainda hoje, mais de trinta anos após o advento do SUS, a proposta de se implementar um modelo fundamentado em universalidade, equidade e integralidade de acesso à saúde, em especial em um país historicamente desigual e injusto, permanece como uma conquista inegável e um posicionamento corajoso em defesa da melhoria da qualidade de vida da população, sobretudo dos estratos sociais mais empobrecidos. O modelo da cidadania regulada (Telles, 2006), que por tanto tempo foi o prevalente no país e que deixava à margem dos direitos sociais grande parte da população, seja por critérios de renda, escolaridade, vínculo empregatício, gênero, cor/raça, foi ultrapassado, ainda que não completamente, com o advento do SUS.

Nesse sentido, a atual conjuntura vivenciada no Brasil, marcada pela emergência de discursos antidemocráticos e notadamente elitistas, privatizantes e mercadológicos, 
configura-se, para além de uma retórica vazia, em sérias ameaças à manutenção de direitos sociais duramente conquistados e ainda carentes de consolidação e expansão. Se, em nosso país, nunca chegou a configurar-se um Estado de bem-estar social, mas apenas conquistas em áreas pontuais, o contexto atual mostra-se cada vez mais propício ao desmonte de direitos que, até então, pareciam já fronteira ultrapassada. O avanço de um capitalismo voraz, encampado por setores historicamente conservadores, tem encontrado sua expressão mais predatória por meio do discurso público de que o Estado deve ser cada vez menor para que seja mais eficiente. A exemplo podem ser citadas a criação de setores, na União e nos estados, cuja finalidade é promover a desestatização (Minas Gerais, 2019). Esse entendimento, contudo, aplicar-se-ia somente à restrição e/ou ao contingenciamento de recursos públicos essenciais para manutenção e expansão de políticas públicas, enquanto, para o grande capital, não se restringiriam benesses facultadas pelo financiamento público (Turtelli, Fernandes, Rodrigues, 18 jun. 2019).

Em outra frente, a aprovação da proposta de Reforma da Previdência, ainda em tramitação, configura-se em panorama extremamente desanimador para os trabalhadores do país, pois, ao elevar os requisitos para acesso aos benefícios previdenciários, bem como descaracterizar sua função de solidariedade social, por meio da possibilidade de adoção do sistema de capitalização, implicará, cada vez mais, a piora das condições de vida e trabalho da população, obrigada a estender os limites da vida ativa para além do que seria então, razoavelmente desejado (Nuzzi, 17 jun. 2019). A perversidade dessa proposta se revela ainda mais cruel para trabalhadores rurais e do campo, operários, bem como para mulheres e todas as categorias cujo desgaste decorrente do trabalho é ainda mais intenso. Esse cenário torna-se ainda mais complexo e pessimista tendo em vista a proposta de emenda constitucional do corte dos gastos, que congela os investimentos sociais em saúde e educação pelos próximos vinte anos (Moretti, 25 set. 2018). Para o SUS, a combinação de cortes em direitos sociais e piora das condições de vida e saúde da população brasileira pode trazer ainda mais demandas, que, a manter-se o atual panorama, serão cada vez menos atendidas.

A nova Pnab não pode ser analisada fora desse contexto que traz como horizonte sérias consequências para o campo da saúde pública no Brasil, o que é especialmente preocupante, considerando-se a importância da ESF para a consolidação do SUS no país. A partir dessa perspectiva, faz-se cada vez mais necessário refletir sobre a estrutura e os princípios da ESF, tendo em vista colaborar para fortalecê-la como foco estruturante da ABS no Brasil. A ESF, como já indica seu nome, tem como cerne a saúde da família. A Pnab (Brasil, 2017) apresenta e detalha a ESF, mencionando suas diretrizes, estrutura e funcionamento. Contudo, é apenas em seu anexo, no "Capítulo I: Das disposições gerais da atenção básica à saúde", que é apresentada uma descrição de família, restrita a menos de três linhas: "A família, a comunidade e outras formas de coletividade são elementos relevantes, muitas vezes condicionantes ou determinantes na vida das pessoas e, por consequência, no cuidado". Em relação ao Núcleo Ampliado de Saúde da Família e Atenção Básica (Nasf$\mathrm{AB})$, anteriormente denominado Núcleo de Apoio à Saúde da Família (Nasf), o texto da Pnab (Brasil, 2017) determina que seu processo de trabalho deve ser estabelecido "a partir de problemas, demandas e necessidades de saúde de pessoas e grupos sociais em seus territórios", não mencionando as famílias e suas necessidades de saúde. Considerando-se 
a importante atuação do Nasf no suporte às equipes da ESF, tendo em vista a construção de uma clínica ampliada (Fernandes, Souza, Rodrigues, 2019), é digno de nota que o texto da Pnab (Brasil, 2017) não ressalte o papel estratégico dos Nasf. Além disso, segundo Melo et al. (2018, p.329):

Ainda que nessa PNAB não tenha havido mudanças estruturais importantes no Nasf, chama a atenção o fato de que ela amplia sua responsabilidade para as chamadas equipes de $\mathrm{AB}$ tradicionais, retira o termo apoio da sua nomenclatura, gerando dúvidas sobre o lugar que o matriciamento passa a ter aos gestores responsáveis pela implementação das mudanças, além de colocar em risco a própria ESF.

Políticas públicas de cunho universal e integral como a ESF constituem importante alteração de paradigmas em um modelo de cidadania à brasileira, que, como citado, só a duras penas passou de uma visão reducionista e estimagtizante, que deixava à margem diversas categorias sociais, para uma concepção fundada em princípios de igualdade e universalidade (Telles, 2006). Políticas universais destinam-se à totalidade da população, sendo assim, políticas públicas dirigidas à família devem dirigir-se a todas as famílias. No Brasil, o arcabouço legal define o que se considera família, e, até pouco tempo atrás, incluía apenas aquelas constituídas pela união de um homem e uma mulher, excluindo assim outros arranjos, tais como os homoafetivos. Considerando-se, conforme mencionado, que ainda recentemente se verificam embates em torno da definição de família pela legislação brasileira, permanece relevante discutir sobre a apropriação do conceito de família por programas e políticas públicas, já que as definições reconhecidas pela legislação se constituem em uma das dimensões relacionadas à conquista de direitos e cidadania.

Todavia, apesar de elegerem a família como unidade de atenção, nem sempre os programas e as políticas contemplam uma discussão aprofundada e mais detida sobre as implicações decorrentes de se trabalhar de acordo com essa definição. No caso da ESF, a ausência de uma discussão aprofundada sobre o conceito de família pode ser considerada reflexo de uma abordagem comum no campo da saúde, que sob a influência do modelo biomédico muitas vezes define família a partir de um olhar estritamente biológico, restrito a aspectos relacionados aos ciclos da vida, ligados ao sexo e à faixa etária. A despeito da emergência de outros referenciais e abordagens, o modelo biomédico permanece como discurso hegemônico no campo da medicina, constituindo-se em "referencial técnico-instrumental das biociências" (De Marco, 2006, p.64), tendo como uma de suas características não levar em consideração "o contexto psicossocial dos significados, dos quais uma compreensão plena e adequada dos pacientes e suas doenças depende" (p.64). Sendo assim, essa concepção pode levar a uma abordagem fragmentada, que compreende a saúde da família apenas a partir da saúde de seus componentes, tendo em vista o sexo e/ou a idade: saúde da mulher, da gestante, da criança, do homem e do idoso, desconsiderando ou minimizando a necessidade de se ter em conta as dinâmicas e o funcionamento dos diversos arranjos familiares. Ainda que a ESF e o Nasf-AB tenham como premissa a construção de uma clínica ampliada - que leve em consideração o contexto e as necessidades dos sujeitos, inclusive na elaboração dos projetos terapêuticos, de forma a estimular a autonomia e a implicação da população atendida - e que sejam inegáveis os avanços proporcionados pela 
ESF para a ampliação do acesso e da qualidade do cuidado em saúde (Macinko, Mendonça, 2018), a ausência de uma definição mais detida acerca de família na Pnab (Brasil, 2017), bem como as conclusões de estudos e pesquisas sobre a ESF (Fernandes, Souza, Rodrigues, 2019; Peruzo et al., 2018; Melo et al., 2018; Brito, Mendes, Santos Neto, 2018; Penna et al., 2016; Baltor, 2012; Dalpiaz, Stedile, 2011; Gabardo et al., 2009; Fonseca, 2005; Ermel, Fracoli, 2006; Silva et al., 2011; Trad, 2010; Ribeiro, 2004; Alonso, 2003) converge para a constatação de que, desde sua implementação até os dias atuais, apesar do caráter de integralidade do SUS e, assim, da ESF, é preciso reforçar que por família se compreendem os diversos formatos e arranjos existentes na sociedade brasileira, sendo também necessário fortalecer e ampliar, na legislação referente à Estratégia, as orientações acerca de como a equipe de saúde da família deve construir ações que tenham, de fato, a família como foco.

Considerando esses aspectos, o presente artigo tem como objetivo apresentar uma reflexão, a partir de abordagens clássicas e contemporâneas, nos campos das ciências humanas e sociais, sobre família e parentesco. Tendo em vista a centralidade que a família tem como norte de políticas públicas, essa reflexão, baseada em parte da vasta literatura sobre o tema, procura apresentar e sintetizar algumas das principais correntes teóricas. São comentados autores "clássicos" da sociologia, da antropologia e da história, tais como Durkheim, Parsons, Lévi-Strauss, Radcliffe-Brown, Malinowski, Ariès, e discussões mais contemporâneas nessas disciplinas, que relacionaram à análise da família as temáticas de gênero, classe social, entre outras (Klaas Woortmann, Strathern, Janet Carsten, Andrée Michel, Segalen, Singly). São também apresentadas reflexões específicas sobre a realidade brasileira, a partir de estudos de Gilberto Freyre e Oliveira Vianna, que analisaram o papel da família na constituição da nação e da cultura brasileira desde o período colonial. Esta análise inclui as contribuições de pesquisas que têm se debruçado sobre a temática das relações entre família e poder no Brasil, revitalizando e atualizando a reflexão sobre estruturas de poder político e econômico e origens familiares (Oliveira, 2018).

A abordagem aqui proporcionada, considerando o contexto econômico e político atual do país, caracterizado, de um lado, por corte de investimentos em saúde e, de outro, por uma forte investida conservadora que busca deixar à margem das políticas públicas aqueles atores sociais considerados "inadequados", seja por critérios de cor/raça, gênero, orientação ideológica ou outros, que não se coadunam com o atual discurso cristão fundamentalista, heteronormativo, tendo como molde valores do imperialismo norte-americano - simbolizado nos discursos que circulam a partir das falas e dos posicionamentos defendidos pelo atual governo brasileiro -, visa colaborar para a reflexão sobre as implicações decorrentes de se eleger a família como foco de políticas públicas.

\section{Estudos sobre família e parentesco: das abordagens antropológicas às contribuições das teorias feministas e dos estudos de gênero}

Estudos em antropologia, sociologia, história e em outras ciências sociais e humanas desenvolveram, ao longo do tempo, uma diversidade de abordagens que examinaram (e examinam) a família e o parentesco considerando concepções/definiçõos, modelos, estruturas, funções, diversidade e/ou universalidade. Conforme Hita (2005), em uma 
primeira fase, predominaram as abordagens de caráter evolucionista, com ênfase na ideia da existência, ao longo da história, de diferentes estágios da família, que caminhariam sempre no sentido de uma evolução ou aperfeiçoamento dessa instituição. A exemplo, podem ser citados os estudos de Morgan e sua influência sobre a abordagem de Engels (1984) a respeito da origem da família, da propriedade privada e do Estado. Após a Primeira Guerra Mundial, a ênfase passa ao exame da organização e do funcionamento das famílias, com foco no fim das famílias extensas e na transição para o modelo nuclear e a concepção da livre escolha do cônjuge. Conforme essas abordagens, a tendência ao modelo nuclear e o viés afetivo que teria sido adicionado ao casamento, à medida que a escolha conjugal passou cada vez mais a se basear no sentimento, e não na imposição, seriam formas de compensação pelo fim da base patriarcal e do caráter anteriormente extenso da família. Caracterizando um terceiro momento dos estudos sobre família, em meados dos anos 1950, a abordagem parsoniana teria como principal característica a inclusão da função da socialização nas reflexões sobre a família, aspecto até então ausente desses estudos, já que o foco se voltava para a conjugalidade.

Posteriormente, com o desenvolvimento das ciências humanas e sociais, a análise da família tem seu escopo e enfoques ampliados, com a inclusão de novas metodologias e a preocupação com questões referentes ao gênero e à sexualidade. Conforme Torres (2010), seria somente com William Goode (1969) que se encontrariam, entre os estudos anglo-saxões, as primeiras abordagens que reconhecem a mulher como "ator social pleno" (Torres, 2010, p.91). Essa percepção ganharia peso nos anos 1970, com os estudos feministas e sua contribuição para a transição de uma concepção que considerava a mulher somente a partir de aspectos biológicos, em especial a reprodução, para uma compreensão de seu papel como indivíduo não restrito a limites/possibilidades decorrentes de seu corpo biológico (Torres, 2010; Hita, 2005). Desde então, os estudos têm perscrutado, a partir de novos ângulos de análise, temas anteriormente examinados, entre eles a relação entre famílias, poder político e econômico e trajetórias de ascensão política e/ou empresarial no Brasil (Oliveira, 2018). A próxima seção comenta estudos e pesquisas relacionados a essas diversas abordagens.

\section{As origens da família, horda primitiva e tabu do incesto ou: família sempre existiu?}

Conforme mencionado, no campo dos estudos sobre família e parentesco, um dos principais focos de análise constituía-se, inicialmente, na tentativa de estabelecer, a partir da compreensão do funcionamento e da estrutura das sociedades, como seria possível definir família e quais teriam sido os formatos identificados ao longo da história. Teria a família sempre existido, da mesma forma, em todas as sociedades e todo o tempo? $\mathrm{Na}$ impossibilidade de demarcar e remontar precisamente ao estágio inicial da humanidade, aventou-se a possibilidade de ter existido, nesse marco zero, um estado de horda primitiva, no qual não havia organização social alguma, incluindo as famílias, hipótese essa cogitada por Charles Darwin, com sua horda primeva e apropriada pela psicanálise para referenciar aspectos centrais na compreensão da estrutura e do funcionamento do inconsciente (Lima, Souza, 2016). 
$\mathrm{Na}$ antropologia, conforme mencionado, a noção de evolucionismo cultural teria sido encampada por autores como Lewis Henry Morgan e inserida por Engels (1984) em sua formulação sobre a origem da família, da propriedade privada e do Estado. Engels apresenta uma "evolução" da família ao longo do tempo, de acordo com a qual teriam se sucedido a família consanguínea, a punaluana, a sindiásmica e a monogâmica. Esses estágios se diferenciariam por uma gradativa ampliação do alcance do interdito do incesto, inicialmente restrito à proibição das relações entre pais e filhos. Quanto à estrutura das famílias, prevaleciam aquelas formadas por grandes grupos, nos quais os filhos eram filhos da coletividade; passando-se gradativamente para a família monogâmica, formada por um casal (homem e mulher), na qual o adultério ocasional permaneceria como uma possibilidade aberta aos homens, enquanto a infidelidade feminina seria ainda duramente repreendida. As críticas dirigidas a essa abordagem apontam, entre outros aspectos tidos como questionáveis, a sua base em "dados empíricos extremamente limitados, o que leva a uma comparação problemática entre sociedades indígenas contemporâneas e sociedades pré-históricas desaparecidas, baseada apenas na semelhança de saberes e equipamentos culturais" (Carneiro, 29 maio 2015), bem como a expressão de uma visão linear, que configura "um evolucionismo que não leva em conta os processos regressivos de sociedades que decaíram e desapareceram" (Carneiro, 29 maio 2015).

Diferentemente, Lévi-Strauss (1982, p.40) considerava que a presença do ser humano sempre implicaria, de formas mais ou menos elaboradas, a presença da cultura, admitindose, contudo, que a delimitação de um marco zero e a superação de um estágio de horda primitiva "na falta de significação histórica aceitável, apresenta um valor lógico que justifica plenamente sua utilização". Enquanto na antropologia predominava ate então uma explicação do parentesco em analogia com os organismos biológicos, a exemplo da formulação de Radcliffe-Brown (1973), Lévi-Strauss avança ao compreender a necessidade de estudar estruturalmente os objetos, em vez de apenas observá-los e fazer inferências sobre as estruturas sociais a partir de seus aspectos exteriores.

Em Lévi-Strauss (1982), o interdito do incesto tem papel fundante, possibilitando a passagem para a cultura e constituindo-se, ele mesmo, na própria cultura. Para além de uma regra negativa, de proibição, o tabu do incesto permitiria movimentos positivos, que levam à ampliação do círculo e ao reconhecimento do outro. A impossibilidade de constituir uma união conjugal com outro membro do círculo familiar conduz à necessidade de buscar um parceiro externo à família, inaugurando-se, assim, circuitos de troca, em que uma família precisa dar suas mulheres para outra família, que também precisa fazer o mesmo movimento. O casamento teria como base a constituição de alianças e se basearia no princípio da exogamia. O tabu do incesto não se relacionaria a causas biológicas, ou seja, ao pretenso temor de consequências congênitas para a descendência da união proibida, mas à busca da construção de alianças benéficas para a sociedade, sendo, assim, "a proibição do incesto ... a regra suprema da dádiva" (Lévi-Strauss, 1982, p.481). Essa noção de que a família tem origem em um fato social, e não biológico, vai em perspectiva oposta à percepção de Malinowski (1983), para quem a família tem origem essencialmente nos impulsos biológicos e psicológicos dos indivíduos. 
Grosso modo, diversos autores nas ciências sociais atribuem ao tabu do incesto um papel decisivo, tendo em vista o entendimento de que é por meio dele que se possibilita e se efetiva a cultura. Assim, por exemplo, tanto Lévi-Strauss quanto Malinowski reconhecem o papel desse interdito para a cultura, sendo que, para o primeiro, essa interdição tem um caráter essencialmente positivo, de saída do hermetismo da família restrita para a abertura possibilitada pelo circuito da dádiva e da reciprocidade. Já Malinowski (1983) não desconsidera a questão das alianças que se instauram em decorrência da interdição do incesto, porém, acentua o potencial desorganizador que esse evento teria sobre a estrutura familiar e, assim, sobre a função de socialização que deve ser exercida pelas famílias junto aos seus membros mais novos. Conforme Woortmann (2002, p.15), ao comentar a formulação de Malinowski: "Se o incesto é uma tentação universal, ele precisa ser proibido porque ... se fosse permitido, a relação fundamental entre criança e seus pais seria destruída".

A abordagem de Malinowski sobre família e parentesco, construída a partir de sua experiência com os povos do Pacífico, caracteriza-se, entre outros aspectos, por uma forte influência da psicologia e, assim, por uma percepção das escolhas dos indivíduos como forças motrizes das sociedades, mesmo naquelas em que, ao menos em tese, haveria pouco espaço para isso. Por meio do casamento e da família, seria possível acomodar e tornar duráveis sentimentos associados ao estado de paixão inicial e de interesse sexual entre os indivíduos. O casamento seria a celebração de um contrato entre dois indivíduos, o que não impediria sua percepção de que, a cada nova união, se associariam novos movimentos sociais, por meio da construção de circuitos de reciprocidade entre as famílias envolvidas.

\section{Concepções sobre a menor unidade dos sistemas de parentesco: família elementar ou nuclear e o átomo do parentesco em Lévi-Strauss}

As análises sobre as origens da família progressivamente se voltaram para a tentativa de identificar, nos sistemas de parentesco, sua menor unidade. As respostas se concentram, grosso modo, na identificação da família nuclear e/ou elementar como essa unidade inicial (De Coulanges, 1961; Radcliffe-Brown, 1973; Malinowski, 1983, entre outros autores); na proposição de Lévi-Strauss (1973, p.84) de um esquema denominado por ele "átomo do parentesco"; na identificação, em algumas sociedades, da existência de papéis e funções familiares, estando ausente, contudo, a família nuclear ou elementar como menor unidade do parentesco, existindo outras estruturas de organização anteriores à família, típicas de sociedades matrifocais (Fox citado em Woortmann, Woortmann, 2004), além da consideração de que, em algumas sociedades, a menor estrutura do parentesco seria a mãe e seu(s) filho(s) (Adams citado em Woortmann, 2003).

Para Malinowski (1983), da família nuclear derivariam extensões por meio de sucessivas uniões. O fundamento do parentesco constitui-se na exogamia, que seria a extensão dos tabus sexuais dentro da família individual. Já em Lévi-Strauss, a estrutura elementar do parentesco é constituída por relações consanguíneas, relações de aliança e relações de filiação (Lévi-Strauss, 1982; Woortmann, 2003; Sarti, 10 dez. 2009). A menor unidade desse sistema ou o "átomo do parentesco" seria diretamente relacionado à proibição do incesto e demandaria uma relação em quatro níveis diferenciados: marido e mulher, pai e filho, irmão e irmã e entre tio por parte de mãe e seu sobrinho. A existência dessa unidade 
fundamental tem como pressuposto um sistema de trocas entre dois grupos: um que dá e outro que recebe a mulher. Nesse sentido, o esquema proposto introduz uma figura com um papel até então não reconhecido no sistema de parentesco: o irmão da mãe, que, ao abrir mão de sua irmã, possibilita que um homem externo à família se case com ela. Conforme Sarti (10 dez. 2009; destaque no original): “Assim, Lévi-Strauss ... introduz a noção de que o irmão da mãe não é um 'elemento extrínseco', mas 'um dado imediato da estrutura familial mais simples'”. Indo além das superfícies aparentes das estruturas e dos fatos sociais, ao fim e ao cabo, "as regras de casamento são variadas maneiras de garantir a circulação de mulheres, isto é, substituir um sistema de relações consanguíneas, de origem biológica por um sistema de aliança" (Lévi-Strauss, 1973, p.76).

Diferentemente de Radcliffe-Brown, Lévi-Strauss não considerava a família a origem das sociedades ou do parentesco, mas a troca, possibilitada pelo tabu do incesto, uma vez que a sociedade só poderia existir em oposição à família, permitindo sua duração por um período restrito. A exogamia teria como mérito possibilitar a coesão social, por meio da superação do estado de autossuficiência da família consanguínea, e, assim, a saída da esfera da natureza, consubstanciada no polo da consanguinidade, para a esfera da cultura, por meio da aliança. Para Lévi-Strauss, é a divisão sexual do trabalho, ao tornar os sexos interdependentes entre si, que torna o casamento necessário.

Em Radcliffe-Brown (1973), conforme mencionado, a família nuclear se constitui na menor unidade do sistema de parentesco e afinidade, sendo a reprodução a finalidade essencial de sua existência. Nesse sentido, casais sem filhos não poderiam ser considerados, de fato, famílias. O sistema de parentesco e afinidade, estruturado a partir da família elementar, ramificar-se-ia em níveis distintos, diferenciados a partir dos tipos de relações entre seus componentes e dos vínculos consanguíneos e/ou de afinidade existentes entre eles. Por meio de sucessivas uniões entre componentes oriundos de famílias elementares distintas, as relações genealógicas tenderiam a se expandir continuamente. Sendo assim, o sistema de parentesco é examinado por Brown a partir das relações de pessoa a pessoa, constituindo uma percepção individualista do parentesco.

Por sua vez, a análise desenvolvida pelo historiador francês De Coulanges (1961), originalmente publicada em 1864, constrói uma extensa análise sobre as instituições sociais, entre elas a família. Comparando os costumes, a cultura e as estruturas de sociedades desde a Antiguidade, o autor comenta que, em Roma e na Grécia, a instituição família foi constituída pela religião, que teria também instituído o casamento e a figura da autoridade paterna, determinando assim as linhas de parentesco e tendo como base o direito de propriedade e de sua transmissão por meio da herança. Para De Coulanges, na Antiguidade a estrutura social era pouco desenvolvida, e as famílias eram praticamente autossuficientes, relacionando-se por meio da descendência, organizando-se em extensas redes de relações que compartilhavam o culto aos mesmos deuses e se reconheciam por meio de deveres e direitos recíprocos. Denominada gens, essa família ampliada teria influenciado o funcionamento das sociedades na Antiguidade grega e romana durante vários séculos, até seu enfraquecimento ocasionado pelo desgaste dos vínculos entre seus componentes em decorrência das alterações estruturais nas sociedades ao longo do tempo, em especial o surgimento das cidades (Silva, s.d.). A centralidade da religião na organização 
e funcionamento dessas sociedades trazia como característica uma forte imbricação entre mortos e vivos, que se refletia nas famílias, baseadas também no dever da procriação para a não interrupção da descendência. Continuar a linhagem era a justificativa para o Levirato, que permitia a união da esposa de um homem infértil com seu cunhado, sendo que os filhos daí advindos seriam considerados filhos do primeiro marido, o mesmo ocorrendo no caso das viúvas.

\section{As abordagens funcionalistas sobre família: Durkheim e Parsons}

Ao longo do tempo, os estudos passaram suas lentes, do esforço em definir família e parentesco, para uma tentativa de compreender suas funções. Nesse sentido, a corrente funcionalista proporcionou importantes reflexões, a exemplo da análise de Durkheim, que evidencia a transição da família patriarcal e/ou paternal para a família de tipo conjugal moderna, além de valorizar o papel do indivíduo em relação ao coletivo da família, ao mesmo tempo que ressalta o papel de maior intervenção estatal no contexto de organização desse arranjo familiar (Durkheim, 1975a, 1975b). Entre outros aspectos, Durkheim considerava que a família moderna teria sido fundada pelo casamento e que, apesar da persistência, em algum nível, da influência familiar sobre a escolha do cônjuge, o reforço à autonomia dos filhos em relação aos pais tornaria cada vez mais a escolha do parceiro como de livre opção. Por sua vez, sua percepção de que, com o decorrer do tempo, o instituto da herança deixaria de ter papel central na transmissão de posses e capitais não se concretizou, permanecendo, pelo contrário, como uma das funções da família nas sociedades capitalistas contemporâneas e relacionando-se fortemente à persistência das desigualdades sociais, tal como apontado por Bourdieu $(1974,1975,2003)$, para quem a família é o lócus de transmissão e reprodução de diversos tipos de capitais socialmente valorizados, tais como o cultural, o social e o econômico.

Por sua vez, aproximando-se de Durkheim e, de certo modo, fazendo uma releitura de conceitos freudianos, Parsons (1966; Parsons, Bales, 1955) considerava que a ação humana segue regras e modelos que a estruturam, sendo esses modelos internalizados pela criança em seu processo de desenvolvimento. É nesse escopo de um funcionalismo com caráter evolutivo que Parsons analisa a família. Por considerar o estágio industrial das sociedades modernas a forma mais avançada possível de organização social, Parsons também considerava a família nuclear, notadamente o modelo americano, um modelo-padrão, sendo os demais formatos e arranjos distantes do ideal/idealizado nessa formulação teórica. A família analisada pelo sociólogo norte-americano é aquela dos anos 1950, logo, a que se enquadrava no formato Wasp, sigla em inglês para "branca, anglo-saxã e protestante", encarnando assim todos os valores sociais que demonstrariam a superioridade da cultura e da nação norte-americanas, devido ao seu "progresso" capitalista e ao ideal de democracia e meritocracia. Como parte da formulação de Parsons sobre uma teoria geral da ação, sua teoria da personalidade e socialização pode ser periodicizada em quatro fases que, a partir da teoria psicanalítica, se enquadrariam em um primeiro momento de dependência total do bebê em relação à sua mãe, seguido por uma fase de sentimento amoroso e de diferenciação entre os pais e o eu. O terceiro período seria a crise de Édipo e um estado de latência, finalizando com a 
maturidade. Com foco no que denominou terceira fase do desenvolvimento da socialização e da personalidade, Parsons considerava que os processos de socialização, de forma progressiva, vão conferindo autonomia à criança e retirando-a do estado de dependência para com a mãe, e, assim, a criança progride de um sistema de solidariedade centrado na mãe para um sistema de solidariedade centrado na família.

As críticas à abordagem parsoniana e sua apropriação da teoria psicanalítica evidenciam a superficialidade com que essa apropriação é feita, uma vez que são esvaziados os processos e os conteúdos relacionados à libido e aos instintos no desenvolvimento da personalidade, sendo considerados somente os papéis desempenhados pelos progenitores no âmbito da família. A socialização se resumiria ao entendimento de que as meninas aprendem a ser mulheres imitando suas mães e os meninos aprendem a ser homens imitando seus pais. A família em Parsons tem essencialmente duas funções: socializar os filhos e estabilizar a personalidade dos adultos, funções que seriam realizadas por meio do desempenho de papéis sexuais, mecanismos por meio dos quais as pessoas são integradas em sistemas de ação. Os papéis seriam quatro, construídos a partir de dois eixos de diferenciação, um eixo de poder, que diferencia papéis de pais e filhos, e um eixo instrumental - expressivo, que se refere às diferenças entre homens e mulheres, sendo que os homens exerceriam papéis instrumentais e a mulher, os expressivos. As análises críticas sobre a formulação de Parsons apontam a importância de se ter incluído no rol de funções da família a socialização e problematizam, entre outros aspectos, a patologização de outros modelos familiares (Hita, 2005; Torres, 2010) e a divisão rígida de papéis que seriam exercidos por homens e mulheres: "Ao não conseguirem diferenciar e descolar o sexo do gênero, os parsonianos terminaram essencializando de certa forma relações que em princípio não eram concebidas como tais neste modelo" (Hita, 2005, p.127-128).

\section{Família e gênero: os estudos feministas}

Com o advento dos estudos feministas, no âmbito dos estudos sobre família, as abordagens então dominantes, que atribuíam à mulher um papel de submissão ao homem e de desempenho da função exclusivamente doméstica de criação dos filhos, começam a ser questionadas. Esses estudos desnaturalizaram concepções de gênero e sexo, evidenciando seu caráter histórico e social (Strathern, 2017; Michel, 1983). A princípio com foco mais restrito à denúncia das desigualdades entre homens e mulheres, essas pesquisas permitiram nomear fenômenos como a opressão e dominação masculinas (Torres, 2010; Hita, 2005). Na sociologia francesa, as pesquisas de Andrée Michel (1983) auxiliaram a elaboração de críticas à abordagem de Parsons, ao evidenciar a dimensão produtiva do trabalho doméstico, ou seja, seu valor econômico e de troca, e apontar inúmeros aspectos positivos do desempenho dos papéis expressivo e instrumental tanto por homens quanto por mulheres. A intensificação da presença da mulher no mercado de trabalho, analisada a partir de seus aspectos positivos, demonstrou que os ganhos em termos tanto econômicos quanto de autoestima para as mulheres beneficiariam também suas famílias, sendo esses ganhos potencializados quando se institui uma efetiva rede de apoio à maternidade por meio de políticas públicas. Por sua vez, quanto aos aspectos não tão positivos dessa inserção, foi destacada a dificuldade de 
conciliação de carreira, maternidade e trabalho doméstico. Em países como o Brasil, onde não chegou a se constituir um Estado de bem-estar social, esse seria um fator especialmente dificultador da inserção das mulheres no mercado de trabalho, especialmente para aquelas pertencentes às camadas populares, que conciliam, com pouco ou escasso apoio público, as duplas jornadas que desempenham em seu cotidiano, realidade que permanece pouco alterada nos dias atuais (Verdélio, 6 mar. 2017).

A questão do gênero, em especial da mulher e da maternidade, por muito tempo romantizada e idealizada como ápice da existência da mulher e objetivo maior de sua existência, foi também questionada por estudos realizados a partir dos anos 1960 e 1970 que demonstraram a queda na percepção das mulheres quanto à sua felicidade conjugal após o nascimento dos filhos, o que também se constatava em relação àquelas famílias nas quais apenas a mulher desempenhava as tarefas domésticas (Michel, 1983). A divisão sexual do trabalho, anteriormente aos estudos feministas abordada a partir apenas de seu viés positivo, passa a ser considerada tendo em vista os efeitos subjetivos que acarretava ao ambiente familiar, sobretudo à infelicidade das mulheres.

A correlação entre gênero e família, em estudos brasileiros, teve em Klaas Woortmann (1987; Woortmann, Woortmann, 2004), um de seus primeiros expoentes. Estudioso de temas ligados à família e ao parentesco, Klaas realizou pesquisa com famílias pobres de Salvador, na Bahia, tendo identificado forte componente associado à matrifocalidade nesses grupos. Influenciado, entre outros autores, por Leach e Bourdieu, Klaas realizou também estudos etnográficos com camponeses brasileiros (Schwade, Woortmann, 16 mar. 2015; Woortmann, 1990), tendo recorrido a Pierre Bourdieu para compreender e identificar, entre esses grupos, o funcionamento de um mercado matrimonial, pautado pela utilização de estratégias que demonstravam que as escolhas conjugais embutiam um componente não aleatório ou de acaso, já que era possível identificar que os casamentos seguiam um padrão preferencial, voltado para as uniões que reforçariam as relações de parentesco já existentes e ajudariam a manter a forte relação com a terra nessas comunidades.

Por sua vez, os enfoques específicos sobre famílias LGBT têm também proporcionado a ampliação dos temas e de suas abordagens. No caso brasileiro, o desenvolvimento dessa linha se intensificou à medida que se intensificaram as demandas e os movimentos sociais que visam à garantia de direitos para as famílias constituídas por gays, lésbicas, bissexuais e transgêneros (Nichnig; 2019; Grossi, 2003). A conquista de cidadania e o reconhecimento da legitimidade desses modelos familiares se ancoram, entre outras questões, em um princípio mais amplo, de reconhecimento das identidades e individualidades, no sentido proposto por Stuart Hall. Nesse sentido, marco histórico no Brasil consistiu, em 2011, a decisão do STF determinando que a "união contínua, pública e duradoura entre duas pessoas do mesmo sexo seja considerada união estável, como entidade familiar, conforme determina a Constituição em seu artigo 226 e no Código Civil Brasileiro em seu artigo 1273" (Nichnig, 2019, p.162). Quanto ao casamento, foi apenas em 2013, por meio de resolução do Conselho Nacional de Justiça, que se determinou seu registro pelos cartórios.

Comentando a evolução da legislação brasileira sobre família e conjugalidade, Nichnig afirma que foi somente com a Constituição Federal, em 1988, que se passou a reconhecer como família os casais heterossexuais que não formalizaram, por meio de registro civil, suas 
uniões. Esse passo significativo para a ampliação jurídica do conceito de família, no entanto, não incluiu famílias homoafetivas. Em 2002, o novo Código Civil brasileiro (Brasil, 2002) especificou que a possibilidade de reconhecimento de união estável se dirigia aos casais formados por homem e mulher. Assim, o fato de a legislação brasileira até recentemente não incluir no rol das famílias os casais e famílias homoafetivos reforça, na decisão de 2011 do STF, "um forte efeito simbólico, pois produz reconhecimentos e consequentemente produz direitos para os casais. Se estes casais não tinham a igualdade jurídica em relação aos casais heterossexuais, a decisão do STF vem suprir esta lacuna legislativa, mesmo que essa não positivação do direito traga incertezas jurídicas" (Nichnig, 2019, p.164). Comparando o contexto político e institucional vivenciado no Brasil em 2011 com o atual momento, a autora reflete que, então, se vivenciava um período mais favorável à discussão da temática de gênero e sexualidade, diferentemente de agora, quando essa abordagem tem sido fortemente rechaçada e rotulada, por setores conservadores, como "ideologia de gênero". O que reforça, contudo, a necessidade de manter vigilância em torno das conquistas sociais obtidas nos últimos anos, de forma a que o reconhecimento legal das famílias homoafetivas e outros direitos não venham a ser obstados por retrocessos, tais como a anteriormente citada lei do Distrito Federal que tentou, em 2018, definir como família sujeito de políticas públicas apenas a heterossexual.

\section{Outras abordagens sobre família e parentesco}

Entre as abordagens contemporâneas da temática família e parentesco, além do gênero, como já mencionado, analisado a partir do viés dos estudos feministas e das famílias homoafetivas e, mais recentemente, tendo em vista os conceitos de masculinidade e parentalidade (Nogueira, Miranda, 2017; Wall, Aboim, Cunha, 2010), os estudos têm se voltado para temas como a relação entre classe social e pertencimento familiar (Fonseca, 2005), impacto das tecnologias reprodutivas no entendimento de família (Carsten, 2014), família, identidades e individualização (Segalen, 2013; Rocha et al., 2001; Singly, 2007, 2000), bem como análises sobre dimensões materiais e não materiais do parentesco, tais como as substâncias corporais, sangue e outros fluidos, aspectos menos tangíveis, contudo, ao mesmo tempo, portadores de um peso simbólico muito significativo, tema que não é exatamente novo, mas revisitado e aprofundado nos últimos anos (Carsten, 2014). Amparando-se no conceito de "mutualidade do ser", elaborado por Marshall Sahlins, segundo o qual, em diversas sociedades e em diversos períodos históricos, os parentes participam da vida uns dos outros, o que constituiria uma espécie de compartilhamento da existência, Carsten reflete sobre "a matéria do parentesco", mais especificamente o sangue. Em comum com outros estudos desenvolvidos nos últimos anos na antropologia, essa perspectiva considera importante buscar compreender as diversas formas por meio das quais o parentesco se reinventa: "Aparecendo em diferentes formas com efeitos diferentes: alimentação, terra, procriação, memória, emoção e experiência, para mencionar alguns aspectos que se enquadram na noção de 'mutualidade do ser"' (Carsten, 2014, p.105; destaques no original).

Se em suas origens a antropologia se dedicou a definir o que é e o que não é parentesco, o foco mais recentemente tem sido "as formas com que o parentesco se acumula ou se dissolve ao longo do tempo - em processos de 'espessamento ou diluição de relacionalidades'” 
(Carsten, 2014, p.106; destaques no original). Comprovado pela biologia e pela medicina, o sangue e demais materiais genéticos carregam atributos específicos de cada família, utilizados para comprovação de exames de paternidade, tais como os testes de DNA. O caráter simbólico do sangue definiria, juntamente com outros constructos sociais, culturais e biológicos os limites que separam o "nós" e o eles. Na mesma linha da reflexão sobre as substâncias e o parentesco, Carsten aponta as qualidades imateriais de substâncias como fotografias, cartas, documentos, como capazes de evocar outras dimensões do parentesco, para além do momento presente, relacionando outros espaços e eventos que constroem e são eles mesmos também parte do parentesco.

Segalen - em entrevista concedida a Rocha et al. (2001) -, em relação às tendências que têm sido registradas nas pesquisas sobre família e parentesco nas últimas décadas, comenta como as alterações sociais, a exemplo da maior urbanização, implicaram desafios para a pesquisa etnográfica com família, uma vez que "até os anos 60, a questão do parentesco, trabalho, transmissão, sucessão, enfim, tudo isto, tinha uma evidência e exterioridade. Atualmente tudo se mostra de uma forma mais desarticulada, menos transparente" (Rocha et al., 2001, p.282), sendo bem mais complexo etnografar "o parentesco, no meio urbano. Observar o quê? Por onde começar", se interroga a pesquisadora (p.282). Apesar da permanência de rituais que se associam ao parentesco no mundo contemporâneo, para acessar a família, o pesquisador deve atuar de forma cautelosa e flexível. Segalen acentua a interdisciplinaridade que a temática da família e do parentesco vem ganhando no mundo atual, tendo em vista os interesses e as questões que gravitam em torno de temas como a medicina reprodutiva, por exemplo, que trazem novos aspectos relacionados a essa temática. O tema da identidade, em correlação com a identidade familiar, a origem geográfica, os deslocamentos culturais e geográficos, foi, durante certo período, central nos estudos de Segalen, importância que posteriormente se deslocou para outros enfoques, como a diversidade dos papéis atribuídos aos avós em diversas culturas ao redor do mundo, a correlação entre parentesco e classes sociais, entre outras temáticas (Segalen, 2013; Rocha et al., 2001).

Já François Singly $(2000,2007)$ analisa as relações entre o nascimento do indivíduo individualizado e seus efeitos na vida conjugal e familiar. Examinando as famílias contemporâneas na Europa, em especial na França, Singly ressalta que houve, a partir de meados da década de 1960, uma alteração essencial em relação à concepção de indivíduo, tendo em vista sua identificação em relação aos seus grupos de origem e pertencimento. Esse indivíduo individualizado, que necessariamente tem sua verdadeira identidade possibilitada no contato e na relação com o outro, caracteriza-se por uma busca da autonomia e tem espaço privilegiado no âmago de relações privadas, entre elas, a família e a conjugalidade. Assim:

Nas sociedades individualistas, 'a família' (qualquer que seja a forma ou a estrutura) toma para si a função de (tentar) consolidar em permanência o 'eu' dos adultos e das crianças. ... Consequentemente, a família mudou para produzir esses indivíduos. ... Esquematicamente, o período do final dos anos 1960, no qual ainda vivemos, corresponde à instauração de um compromisso entre as reivindicações dos indivíduos em se tornarem autônomos e seus desejos de continuar a viver, na esfera privada, com uma ou várias pessoas próximas. É a família que chamo de 'individualista e relacional' (Singly, 2000, p.15; destaques no original). 
A maior parte dos estudos anteriormente citados volta-se para as realidades e contextos de outros países e suas culturas. No Brasil, com o estabelecimento das ciências sociais e humanas, o tema da família foi logo abordado, a partir de análises sobre a formação da identidade da nação, sua história e cultura. Ao longo do tempo, essa abordagem iria acrescentar outros ângulos de análise, conforme desenvolvido na próxima seção deste artigo.

\section{Família brasileira}

Os estudos sobre família e parentesco no Brasil não podem prescindir das análises clássicas de Gilberto Freyre, Sérgio Buarque de Holanda, Oliveira Vianna, entre outros autores que examinaram a constituição do Brasil e evidenciaram o papel fundante que determinado tipo de família exerceu, e ainda exerce de certa forma, na construção de um habitus brasileiro: a família patriarcal brasileira. Em Freyre, a família tem destaque, sendo considerada a unidade colonizadora do país, com papel mais relevante do que outras instituições. No período colonial, a família patriarcal era caracterizada, além do domínio da figura masculina, por sua autossuficiência, erigida em torno de uma estrutura diversificada em termos de recursos e potencialidades: a casa-grande, a senzala, os cultivos, as criações de animais, por vezes também uma pequena escola, a capela etc. Ao mesmo tempo que fechada em si mesma, essa família se relacionava com o entorno, por meio da prestação de serviços não disponibilizados pelo Estado, cuja presença no cenário nacional era então, difusa e incipiente (Freyre, 1999). A família patriarcal brasileira se erigiu sob um sistema escravocrata, latifundiário e com base na monocultura. Conhecido por sua definição de uma democracia racial brasileira, o pensamento de Freyre identifica na família patriarcal um papel central na definição da identidade brasileira, constituída a partir do encontro dos povos de Portugal, da África e dos indígenas brasileiros. Das relações às vezes consentidas e por vezes forçadas entre o branco europeu e as mulheres indígenas e africanas, teria se constituído um tipo de família extensa, que gravitava ao redor da família "oficial" do europeu com sua esposa branca. A visão dessa família como central na constituição da identidade nacional permanece ao longo da obra de Freyre, mesmo quando sua análise examina as alterações na estrutura social, na economia, na arquitetura e na organização das cidades (Alves, 2018).

Por sua vez, Sergio Buarque de Holanda (1995) ressalta a influência de valores culturais portugueses na formação da identidade nacional, a exemplo da cultura do personalismo que, em detrimento de valores coletivos, cultua aspectos que seriam decorrentes do carisma e do mérito individual. Para Holanda, o Estado teve papel central na organização da sociedade brasileira, tendo agido a partir de caráter personalista e autoritário (Alves, 2018). Assim como em Freyre, a família patriarcal seria o lócus organizador da vida no ambiente rural brasileiro colonial e se centrava na autoridade do homem branco dono de terras. Uma das contribuições da abordagem de Holanda consiste na identificação de que, mesmo muito após o fim do formato patriarcal de família, o espírito desse arranjo permanece influenciando a sociedade brasileira (Oliveira, 2018; Itaboraí, 2005). Marcas disso estão na força que a origem de família ainda hoje exerce, uma vez que o sobrenome é tido como mais importante do que as realizações dos indivíduos. 
De modo semelhante, a análise de Oliveira Vianna (1987) ressalta como, no Brasil, a influência da família patriarcal e sua organização em estruturas que ele denomina "clãs" constituíram uma cultura peculiar, baseada nas relações de obrigação e subserviência entre aqueles que não estavam incluídos no eixo principal dos clãs e as famílias que dominavam essas formas de organização. Para Vianna, no Brasil não se chegou a constituir uma nação democrática de fato, mas apenas de aparência, na qual os clãs poderosos dominam as instituições em todos os seus níveis (Vianna, 1987; Oliveira, 2018).

É nesse sentido, a partir da constatação da correlação entre família e poder político como um fenômeno da contemporaneidade, não restrito às origens coloniais e às épocas do Império e da Primeira República no Brasil, que a análise proporcionada pela coletânea organizada por Oliveira (2018) se situa e, assim, se diferencia de estudos produzidos entre as décadas de 1950 e 1990, que, em sua maioria, atrelavam o forte vínculo familiar às estruturas políticas como típico das regiões mais pobres e "atrasadas" do país. Com o objetivo de analisar os fatores por meio dos quais "família importa e explica", são comentadas as fortes e antigas raízes históricas de algumas das principais famílias que dominam as estruturas de poder político no Brasil atualmente. Para além de uma pretensa renovação do cenário político brasileiro, os autores evidenciam como as mesmas famílias, desde o descobrimento do Brasil, revezam-se no controle do país. A título de exemplo, Francisco Antonio Doria examina a genealogia de seu parente João Doria, atual governador de São Paulo e descendente de Fernão Vaz da Costa, Lodisio Centurione Scotto (o banqueiro que financiou a expedição de Colombo) e outras figuras históricas de relevo. A análise é exemplar, pois visa perscrutar como, em algumas gerações, os seus antepassados e os do outro Doria, passaram de burocratas de pouca expressão a ministros e todo tipo de personagem poderoso. A resposta é: o poder foi alcançado por meio da constituição de alianças e redes de relações, mais especificamente por meio de casamentos. A manutenção no poder, até os dias atuais, é mantida pela busca frequente de geração a geração, de associação com figuras oriundas de famílias tão ou mais poderosas. A relação entre família, origem e sobrenome e poder político no Brasil é tão intensa, que fica evidenciada pela constatação de que "cerca de 1/3 dos presidentes brasileiros descendem do casal Braz Teves e Leonor Leme, casal este que viveu em São Vicente por volta de 1600; e se não descendem, aparentam-se no casamento a gente ou dele, do casal Teves-Leme, provém" (Doria, 2018, p.7). Machado (2018), em apresentação ao livro organizado por Oliveira (2018), menciona o impeachment sofrido pela presidente Dilma, ressaltando que, mesmo sem comprovação de crime de responsabilidade, a maioria dos 367 deputados que a depuseram justificou essa opção como um "voto pela família". Considerando as bandeiras defendidas pelos partidos aos quais esses políticos se filiavam à época, cabe questionar a qual família se referiam, uma vez que os programas de seus partidos defendem a noção de liberalismo econômico, enxugamento do Estado e restrição de políticas sociais.

Assim, mesmo com todas as alterações sociais, culturais e econômicas vivenciadas pelo Brasil nos últimos séculos, permaneceria como característica marcante uma cultura de uso do Estado em proveito de determinados grupos sociais, que, conforme Oliveira (2018), representam os interesses de uma elite política e empresarial que abriu mão de algum projeto coletivo de nação para encampar apenas seus próprios interesses. A despeito da 
não permanência da família patriarcal em seu modelo clássico, ou seja, rural, escravocrata, organizado em torno da casa-grande e da senzala, o espírito estruturador dessa família permanece influenciando as relações entre as classes sociais e a estrutura institucional brasileira. Em nome de uma suposta familiaridade, que defende com certa nostalgia a família tradicional brasileira, na verdade, o que se defende é uma relação de apropriação, por parte das elites, das estruturas de poder no país. Mesmo que esse modelo patriarcal tenha sido um entre vários existentes no país desde suas origens, sua força como vetor hegemônico organizador inspirou a constituição das práticas e das instituições nacionais. Contudo, não obstante sua força como modelo instituidor de práticas, longe de ser o único formato de família, a família patriarcal conviveu desde os primórdios da colonização do Brasil com outros formatos.

Estudos que examinaram documentos, inventários e relatos de viajantes estrangeiros permitem ver que, ainda que não oficialmente legitimadas, sempre existiram, no país de maioria católica, famílias formadas por concubinato; uniões extraoficiais; famílias monoparentais, bem como relações entre escravos e proprietários de terras, e assim: "Tantas foram as formas que a família colonial assumiu, que a historiografia recente tem explorado em detalhe suas origens e o caráter das uniões, enfatizando-lhe a multiplicidade e especificidades em função das características regionais da colonização e da estratificação social dos indivíduos" (Algranti, 1997, p.87). Considerando o contexto atual, conforme os dados do Instituto Brasileiro de Geografia e Estatística (IBGE), que apontam para uma tendência crescente de diversificação de formatos, para além de uma novidade, as alterações nos arranjos familiares dizem respeito à busca pela legitimação social de modelos e estruturas muitas vezes já existentes. A compreensão de que arranjos familiares não hegemônicos não são exclusividade da contemporaneidade colabora para a desnaturalização de preconceitos e prenoções que atribuem à "degradação social" a existência de famílias monoparentais ou homoafetivas (Neto, 2017; Penna et al., 2016).

Além de não constituir uma novidade ou fenômeno da contemporaneidade, a diversificação de arranjos familiares tem sido um processo em expansão. Nos últimos séculos, as sociedades têm vivenciado profundas transformações, sendo que, especialmente a partir do século XX, mudanças relacionadas a fatores sociais, econômicos e comportamentais auxiliaram a ocorrência de alterações na composição e nas dinâmicas familiares (Trad, 2010). Em censo demográfico realizado pelo IBGE (2010), foram coletadas informações sobre as famílias brasileiras, tendo sido considerados diversos arranjos familiares, além do formato nuclear constituído pelo casal heterossexual com filhos. Os dados desse censo apontaram uma elevação, em relação ao anterior, de pessoas vivendo sozinhas em "unidades unipessoais", cerca de 6,9 milhões ou 12,1\% dos 57 milhões de unidades domésticas recenseadas. Em 400 mil unidades domésticas, as pessoas residentes não possuíam laços de parentesco, o que também significou uma ampliação em relação ao censo de 2000 . Foi também evidenciada a elevação do número percentual de casais sem filhos, o aumento de um ponto percentual nas famílias monoparentais femininas, que seria maior nas áreas urbanas do que nas rurais, além do crescimento das famílias providas por mulheres.

Mais recentemente, em 2015, a Pesquisa Nacional por Amostragem de Domicílios (Pnad) corroborou as constatações do censo (IBGE, 2016). Séries históricas da Pnad evidenciam 
que, desde 2005, a família nuclear (pai, mãe e filhos) não é mais o modelo predominante nos domicílios do país. A comparação dos dados da Pnad relativos a 2015 e 2005 demonstra uma queda de 7,8 pontos percentuais nesse período, no qual a família nuclear caiu de 50,1\% para $42,3 \%$ dos arranjos encontrados nos lares brasileiros (Neto, 2017). Fatores como a intensificação da presença das mulheres no mercado de trabalho, com a diversificação das funções desempenhadas e dos setores de atuação, impulsionada pela ampliação da presença feminina nos bancos escolares, em todos os ramos e níveis do sistema de ensino, além da legalização do divórcio, da disseminação de métodos anticoncepcionais e dos avanços na medicina reprodutiva entre outros fatores proporcionaram novas possibilidades de configuração da maternidade e da paternidade (Haag, fev. 2012; Priore, Bassanezi, 1997).

Além disso, ao longo dos anos, a sociabilidade e o funcionamento das famílias têm sofrido alterações significativas, decorrentes, em parte, de transformações nas formas como se conceituam as crianças, os adolescentes e os idosos e, assim, no papel e no lugar ocupado por esses sujeitos na estrutura familiar. A exemplo, a noção de infância mudou ao longo do tempo e ainda hoje varia tendo em vista os distintos grupos e sociedades. Na Europa, cujos hábitos e modelos ajudaram a conformar a sociedade brasileira, durante vários séculos as crianças eram consideradas "adultos pequenos", e não se dispensava a elas cuidados e/ou atenção diferenciados (Ariès, 1981). No Brasil, nas primeiras décadas do século XX, era comum que crianças ${ }^{1}$ de 8 anos de idade, notoriamente as pertencentes às famílias das camadas populares, com menos recursos financeiros e mais vulneráveis, cumprissem jornadas de trabalho estafantes nas fábricas (Grunspun, 2000, p.52). Dessa forma, foi preciso um longo caminho até que se passasse a defender a noção de que a criança não é um adulto em miniatura e de que faz jus a cuidados diferenciados, sem os quais está sujeita a índices elevados de mortalidade e adoecimento físico e mental. Esse entendimento se desenvolveu ancorado em teorias e descobertas produzidas nos campos da saúde, da psicologia, da puericultura, da pedagogia, entre outras áreas do conhecimento (Ariès, 1981; Priore, 1999; Freitas, 2016). De "macaquinho impudico" (Ariès, 1981, p.10), a criança passou a ser considerada "sujeito de direitos fundamentais inerentes à pessoa humana", conforme estipula, no Brasil, o artigo $3^{\circ}$ da lei n.8.069, de 13 de julho de 1990, que dispõe sobre o Estatuto da Criança e do Adolescente (Brasil, 16 jul. 1990).

A rebote dessa concepção produziu-se também uma nova função para a família, entidade responsável por nutrir, salvaguardar e educar os indivíduos legalmente considerados crianças e adolescentes. Essas alterações, entre outros fatores, produziram (e são produto de) profundas modificações sociais, das quais decorreram mudanças nas dinâmicas e composições familiares. Desse modo, a reflexão acerca das famílias contemporâneas não pode deixar de levar em consideração as alterações sociais, culturais e comportamentais registradas nos últimos anos, bem como seus impactos no funcionamento familiar. Contudo, a constatação das mudanças mencionadas e de seus impactos sobre os arranjos familiares e suas dinâmicas de funcionamento não pode obscurecer a compreensão de que a diversidade de modelos familiares precede em muito as alterações vivenciadas pela sociedade brasileira nos últimos séculos. Além disso, em concordância com Fonseca (2005), uma importante perspectiva para os estudos sobre família e parentesco passa por compreender como as famílias vivenciam essas conexões, e, assim, como os profissionais 
que interagem com elas podem construir possibilidades de intervenção sem se prender a noções idealizadas de família e seus funcionamentos.

\section{Considerações finais}

Ao longo deste artigo, apresentaram-se algumas das principais abordagens de estudos e pesquisas sobre família e parentesco, construídos a partir das ciências humanas e sociais. A contribuição aqui proporcionada constitui-se em uma aproximação ao campo, que, por sua vastidão e profundidade, é de difícil síntese, porém, de extrema riqueza. Ainda assim, espera-se ter colaborado para uma visão em panorama desses estudos e suas principais tendências. Para além de um campo conceitual, conforme mencionado na introdução deste texto, família é campo de disputas, tendo em vista seu potencial estruturador na formulação e implementação de políticas públicas. Se, no campo dos estudos, há muito tempo o foco já se deslocou da busca pela definição de família, no campo das práticas, no dia a dia, esse embate ainda permanece. Em momentos históricos como o atual contexto brasileiro, marcado pela intensificação de ideologias conservadoras, a família se apresenta como um objeto fértil para intensas disputas, que incluem, desde sua definição, traduzida em dispositivos legais como a Constituição, o Código Civil, e o Estatuto da Família, atualmente em tramitação na Câmara dos Deputados, até seu uso como justificativa para a exclusão e/ ou inclusão de determinados conteúdos nos currículos escolares. Sob a bandeira da "família, propriedade e tradição", tem sido defendida no Brasil uma concepção restrita e patologizante de outros modelos de família. Esses movimentos e concepções, caso não se mantenha uma vigilância efetiva, podem vir a incorrer em retrocessos em todos os níveis e esferas sociais e institucionais, o que inclui o SUS. Política pública internacionalmente reconhecida e que inspira diversos países, o SUS não se encontra a salvo dos retrocessos vivenciados no período recente, de intensificação do neoliberalismo mais predatório, com sua capacidade de desarticulação e desconstrução de avanços nas políticas sociais. Sendo assim, é mister atentar para a manutenção e defesa da bandeira de que é impossível negociar seus princípios fundantes: a universalidade, equidade e integralidade. Pelo contrário, os movimentos devem ser no sentido de consolidar e fortalecer os ganhos inegáveis proporcionados pelo SUS, em especial pela ESF e sua atuação na estruturação da ABS.

Dessa forma, para impedir o desmonte e enfraquecimento da ESF como princípio articulador da atenção básica, e assim evitar os possíveis efeitos negativos decorrentes da nova Pnab (Brasil, 2017), cabe manter estrita vigilância. Assim, são caminhos possíveis, alguns deles já aventados por pesquisas que examinaram a atuação dos profissionais de saúde junto à ESF, o fortalecimento na formação dos profissionais da saúde, em todos os níveis de formação e incluindo a educação permanente; o acesso a reflexões sobre a família, suas funções e dinâmicas de funcionamento; além do municiamento dos profissionais com estratégias para abordar, intervir e acompanhar as famílias, construindo um cuidado cada vez mais qualificado em saúde. No contexto político atual é mister também fortalecer o Nasf no sentido de seu papel de apoiar as equipes de saúde da família, tendo em vista o cuidado ampliado em saúde, além de impedir que se esvazie e se sobrecarregue a figura do agente comunitário de saúde, que desempenha papel essencial na ESF. Em suma, é preciso 
evitar que a adesão a outros modelos estruturantes da ABS, como facultado pela legislação em vigor, enfraqueça e dilua o papel da ESF na consolidação do SUS no Brasil. São tarefas árduas, porém imprescindíveis para que a saúde pública em nosso país permaneça como direito de todos e dever do Estado e que continue a avançar a noção de que todas as famílias são sujeitos de direitos e corresponsáveis pela construção do cuidado em saúde.

\section{NOTA}

${ }^{1}$ Infelizmente, apesar dos avanços nas áreas de direitos sociais e humanos, a exploração do trabalho infantil permanece como chaga aberta na sociedade brasileira. Conforme dados do IBGE relativos a 2013, "o número de trabalhadores precoces corresponde a 5\% da população que tem entre 5 e 17 anos no Brasil" (Brito, 12 jun. 2017).

\section{REFERÊNCIAS}

ALGRANTI, Leila Mezan. Famílias e vida doméstica. In: Novais, Fernando (org.). A história da vida privada no Brasil: cotidiano e vida privada na América portuguesa, v.1. São Paulo: Companhia das Letras, 1997.

ALONSO, Ilca L.K. Luzes e sombras no ritual do encontro entre o universo profissional e o mundo da intimidade familiar: a intervenção profissional na saúde da família em âmbito domiciliar. Tese (Doutorado em Enfermagem) - Universidade Federal de Santa Catarina, Florianopólis, 2003.

ALVES, Alessandro Cavassin. A referência: a família patriarcal brasileira. In: Oliveira, Ricardo Costa de (org.). Família importa e explica: instituições políticas e parentesco no Brasil. São Paulo: LiberArs, 2018.

ARIÈS, Philippe. História social da criança e da família. Rio de Janeiro: LTC-Livros Técnicos e Científicos, 1981.

BALTOR, Marja R.R. et al. Autonomia da família e a relação com os profissionais de saúde. Ciências, Cuidado e Saúde, v.11, n.1, p.44-50, 2012.

BOURDIEU, Pierre. Os três estados do capital cultural. In: Catani, Afrânio; Nogueira, Maria A. (org.). Pierre Bourdieu: escritos de educação. Petrópolis: Vozes, 2003. p.71-78.

BOURDIEU, Pierre. A escola conservadora: as desigualdades frente à escola e à cultura. In: Bourdieu, Pierre; Passeron, Jean Claude. A reprodução: elementos para uma teoria do sistema de ensino. Rio de Janeiro: Edições Francisco Alves, 1975. p.39-64.

BOURDIEU, Pierre. A economia das trocas simbólicas. São Paulo: Perspectiva, 1974.

BRASIL. Constituição da República Federativa do Brasil, 1988. Brasília: Senado Federal/Centro Gráfico. 1988.
BRASÍLIA. Distrito Federal. Lei n.6.160, de 25 de junho de 2018. Institui as diretrizes para implantação da Política Pública de Valorização da Família no Distrito Federal. Sistema Integrado de Normas Jurídicas do Distrito Federal, 2018. Disponível em: http://www.sinj.df.gov.br/sinj/ Norma/afea75838e864d798dc14b237c8dbabc/ Lei_6160_25_06_2018.html. Acesso em: 21 set. 2019.

BRASIL. Lei n.8.080, de 19 de setembro de 1990 . Dispõe sobre as condições para a promoção, proteção e recuperação da saúde, a organização e o funcionamento dos serviços correspondentes e dá outras providências, 20 set. 1990. Disponível em: http://www.planalto.gov.br/ccivil_03/leis/ L8080.htm. Acesso em: 20 jun. 2017.

BRASIL. Lei n.8.069, de 13 de julho de 1990. Dispõe sobre o Estatuto da Criança e do Adolescente e dá outras providências, 16 jul. 1990. Disponível em: http://www.planalto.gov. br/Ccivil_03/leis/L8069.htm. Acesso em: 21 jun. 2017.

BRASIL. Lei n.10.406, de 10 de janeiro de 2002. Institui o Código Civil, 2002. Disponível em: http://www.planalto.gov.br/ccivil_03/leis/2002/ 110406.htm. Acesso em: 12 ago. 2019.

BRASIL. Ministério da Saúde. Portaria n.2.436, de 21 de setembro de 2017. Aprova a Política Nacional de Atenção Básica, estabelecendo a revisão de diretrizes para a organização da Atenção Básica, no âmbito do Sistema Único de Saúde (SUS), 2017. Disponível em: http:// bvsms.saude.gov.br/bvs/saudelegis/gm/2017/ prt2436_22_09_2017.html. Acesso em: 12 ago. 2019.

BRITO, Débora. Brasil registra aumento de trabalho infantil entre crianças de 05 a 09 anos. Agência Brasil, 12 jun. 2017. Disponível 
em: http://agenciabrasil.ebc.com.br/direitoshumanos/noticia/2017-06/brasil-registraaumento-de-casos-de-trabalho-infantil-entre. Acesso em: 10 out. 2017.

BRITO, Geraldo Eduardo Guedes de; MENDES, Antonio da Cruz Gouveia; SANTOS NETO, Pedro Miguel dos. O objeto de trabalho na Estratégia Saúde da Família. Interface, v.22, n.64, p.77-86, 2018.

CARNEIRO, Henrique. A origem da família, da propriedade privada e do Estado: um texto atual. Esquerda Online, 29 maio 2015. Disponível em: https://esquerdaonline.com.br/2015/05/29/aorigem-da-familia-da-propriedade-privada-e-doestado-um-texto-atual. Acesso em: 21 ago. 2017.

CARSTEN, Janet. A matéria do parentesco. Revista de Antropologia da UFSCar, Dossiê Parentesco, v.6, n.2, p.103-118, 2014.

DALPIAZ, Ana K.; STEDILE, Nilva L.R. Estratégia Saúde da Família: reflexão sobre algumas de suas premissas. In: Jornada Internacional de Políticas Públicas: Estado, desenvolvimento e crise do capital, 5., 2011, São Luiz. Anais... São Luiz: UFMA. 2011.

DE COULANGES, Numa-Denys Fustel. A cidade antiga. São Paulo: Editora das Américas, 1961.

DE MARCO, Mário A. Do modelo biomédico ao modelo biopsicossocial: um projeto de educação permanente. Revista Brasileira de Educação Médica, v.30, n.1, p.60-72, 2006.

DORIA, Francisco Antonio. Os genes do poder. In: Oliveira, Ricardo Costa de (org.). Família importa e explica: instituições políticas e parentesco no Brasil. São Paulo: Editora LiberArs, 2018. p.712.

DURKHEIM, Émile. Educação e sociologia. Trad. de Lourenço Filho. São Paulo: Melhoramentos, $1975 a$.

DURKHEIM, Émile. Introduction à la sociologie de la famille. In: Durkheim, Émile. Textes, 3: fonctions sociales et institutions. Présentation de Victor Karady. Paris: Les Éditions de Minuit, 1975b. p.9-34.

ENGELS, Friedrich. A origem da família, da propriedade privada e do Estado. Rio de Janeiro: Civilização Brasileira, 1984.

ERMEL, Regina C.; FRACOLLI, Lislaine. O trabalho das enfermeiras no Programa de Saúde da Família em Marília/SP. Revista da Escola de Enfermagem da USP, v.40, n.4, p.533-539, 2006.

FERNANDES, Elaine Toledo Pitanga; SOUZA, Melissa Nathielle de Lima; RODRIGUES, Suely Maria. Práticas de grupo do Núcleo de Apoio à
Saúde da Família: perspectiva do usuário. Physis: Revista de Saúde Coletiva, v.29, n.1, e290115, p.118, 2019.

FONSECA, Cláudia. Concepções de família e práticas de intervenção: uma contribuição antropológica. Saúde e Sociedade, v.14, n.2, p.5059, 2005. Disponível em: http://www.scielo. br/scielo.php?script=sci_arttext\&pid=S0104$12902005000200006 \& \operatorname{lng}=$ en $\&$ nrm $=$ iso \&tlng $=$ pt. Acesso em: 27 set. 2017.

FREITAS, Marcos C. (org.). História social da infância no Brasil. São Paulo: Cortez, 2016.

FREYRE, Gilberto. Casa-grande \& senzala: formação da família brasileira sob o regime patriarcal. Rio de Janeiro: Record, 1999.

GABARDO, Roseclér M. et al. Arranjos familiares e implicações à saúde na visão dos profissionais do Programa Saúde da Família. Revista de Saúde Pública, v.43, n.1, p.91-97, 2009.

GOODE, William J. Revolução mundial e padrões de família. São Paulo: Edusp, 1969.

GROSSI, Miriam Pillar. Gênero e parentesco: famílias gays e lésbicas no Brasil. Cadernos Pagu, n.21, p.261-280, 2003.

GRUNSPUN, Haim. O trabalho das crianças e dos adolescentes. São Paulo: LTR, 2000.

HAAG, Carlos. Brasil em transição demográfica. Pesquisa Fapesp, n.192, fev. 2012. Disponível em: https://revistapesquisa.fapesp.br/2012/02/27/ brasil-em-transição-demográfica. Acesso em: 20 jun. 2017.

HITA, Maria Gabriela. Pontos, contrapontos e modelos alternativos. Revista AntHropológicas, ano 9, v.16, n.1, p.109-148, 2005.

HOLANDA, Sérgio Buarque de. Raízes do Brasil. São Paulo: Companhia das Letras, 1995.

IBGE (Instituto Brasileiro de Geografia e Estatística). Pesquisa Nacional por Amostra de Domicílios: síntese de indicadores 2015. Rio de Janeiro: IBGE, 2016. Disponível em: https:// biblioteca.ibge.gov.br/visualizacao/livros/ liv98887.pdf. Acesso em: 15 jan. 2019.

IBGE (Instituto Brasileiro de Geografia e Estatística). Censo Demográfico 2010: famílias e domicílios - resultados da amostra. Rio de Janeiro: IBGE, 2010. Disponível em: https:// biblioteca.ibge.gov.br/index.php/bibliotecacatalogo?view=detalhes \&id=797. Acesso em: 15 jan. 2019.

ITABORAÍ, Nathalie Reis. A família colonial e a construção do Brasil: vida doméstica e identidade nacional em Gilberto Freyre, Sérgio 
Buarque de Holanda e Nestor Duarte. Revista AntHropológicas, ano 9, v.16, n.1, p.171-196, 2005.

LÉVI-STRAUSS, Claude. As estruturas elementares do parentesco. Petrópolis: Vozes, 1982.

LÉVI-STRAUSS, Claude. Antropologia estrutural I. Rio de Janeiro: Tempo Brasileiro, 1973.

LIMA, Alan Souza; SOUZA, Maurício Rodrigues. O pai da horda e o supereu: de um prenúncio da instância. Psicologia USP, v.27, n.3, p.420428, 2016. Disponível em: http://www.scielo. br/scielo.php?script=sci_arttext\&pid=S0103$65642016000300420 \& \operatorname{lng}=\mathrm{pt} \& \mathrm{nrm}=$ iso. Acesso em: 18 set. 2019 .

MACHADO, Paulo Pinheiro. Brasil: a ficção republicana e a realidade do nepotismo e do familismo. In: Oliveira, Ricardo Costa de (org.). Família importa e explica: instituições políticas e parentesco no Brasil. São Paulo: Editora LiberArs, 2018. p.13-15.

MACINKO, James; MENDONÇA, Claunara Schilling. Estratégia Saúde da Família, um forte modelo de Atenção Primária à Saúde que traz resultados. Saúde em Debate, v.42, n.esp.1, p.1837, 2018.

MALINOWSKI, Bronislaw. A vida sexual dos selvagens: descrição etnográfica do namoro, do casamento e da vida de família entre os nativos das Ilhas Trobriand. Rio de Janeiro: Francisco Alves Editora, 1983.

MELO, Eduardo Alves et al. Dez anos dos Núcleos de Apoio à Saúde da Família (Nasf): problematizando alguns desafios. Saúde em Debate, v.42, n.esp.1, p.328-340, 2018.

MICHEL, Andrée. Sociologia da família e do casamento. Lisboa: Rés Editora, 1983.

MINAS GERAIS. Lei n.23.304, de 30 de maio de 2019. Estabelece a estrutura orgânica do Poder Executivo do Estado e dá outras providências, 2019. Disponível em: http://jornal.iof.mg.gov. br/xmlui/handle/123456789/220136. Acesso em: 12 ago. 2019.

MORETTI, Bruno. PEC teto dos gastos: uma perda bilionária para o SUS em 2019. Revista IHU, 25 set. 2018. Disponível em: http://www. ihu.unisinos.br/78-noticias/583072-pec-tetodos-gastos-uma-perda-bilionaria-para-o-susem-2019. Acesso em: 15 ago. 2019.

NETO, João. Novos arranjos familiares. Retratos: a Revista do IBGE, n.6, p.16-19, 2017. Disponível em: https://agenciadenoticias.ibge.gov.br/ media/com_mediaibge/arquivos/3ee63778c4cf dcbbe4684937273d15e2.pdf. Acesso em: 15 jan. 2019.
NICHNIG, Claudia Regina. Direitos humanos e o reconhecimento das famílias gays e lésbicas no Brasil: os direitos fundamentais e o julgamento histórico do Supremo Tribunal Federal de 2011. Tempo e Argumento, v.11, n.27, p.1585-1591. 2019.

NOGUEIRA, Christina Gladys de Mingareli; MIRANDA, Marcelo Henrique Gonçalves de. A (re)produção das masculinidades hegemônicas: homens, famílias populares e violações dos direitos humanos. Revista Interritórios, v.3, n.5, p.1-21, 2017.

NUZZI, Vitor. Para centrais e Dieese, reforma da Previdência ainda tem perversidades. Dirigentes avaliaram a greve geral de 14 de junho como positiva e preparam agora entrega de abaixoassinado contra a PEC da Previdência na Câmara e no Senado, 17 jun. 2019. Disponível em: https://www.redebrasilatual.com.br/ destaques/2019/06/centrais-pec-previdenciaperversidades. Acesso em: 21 ago. 2019.

OLIVEIRA, Ricardo Costa de (org.). Família importa e explica: instituições políticas e parentesco no Brasil. São Paulo: Editora LiberArs, 2018.

PARSONS, Talcott. Sociedades: perspectivas evolutivas e comparativas. São Paulo: Pioneira, 1966.

PARSONS, Talcott; BALES, Robert. Family, socialization and interaction process. Glencoe, Illinois: The Free Press of Glencoe, 1955.

PENNA, Cláudia M. de M. et al. Concepções de família na Estratégia Saúde da Família: o olhar do agente comunitário de saúde. Ciências, Cuidado e Saúde, v.15, n.3, p.421-428, 2016.

PERUZO, Helen Emília et al. Os desafios de se trabalhar em equipe na Estratégia Saúde da Família. Escola Anna Nery, v.22, n.4, p.1-19, 2018.

PRIORE, Mary Del (org.). História das crianças no Brasil. São Paulo: Contexto, 1999.

PRIORE, Mary Del; BASSANEZI, Carla (org.). Histórias das mulheres no Brasil. São Paulo: Contexto, 1997.

RADCLIFFE-BROWN, Alfred Reginald. Estrutura e função na sociedade primitiva. Petrópolis: Vozes, 1973.

RIBEIRO, Edilza. As várias abordagens da família no cenário do Programa/Estratégia Saúde da Família (PSF). Revista Latino-Americana de Enfermagem, v.12, n.4, p.658-664, 2004.

ROCHA, Ana Luiza Carvalho da et al. Entrevista com Martine Segalen. Qual é a Antropologia do Parentesco e da família no século XXI? Um diálogo franco e brasileiro com Martine Segalen. Horizontes Antropológicos, v.7, n.16, p.277-295, dez. 2001. 
SARTI, Cyntia Andersen. Parentesco e família. ComCiência: Revista Eletrônica de Jornalismo Científico, 10 dez. 2009. Disponível em: https:// www.comciencia.br/comciencia/handler. php? section $=8 \&$ edicao $=52 \&$ id $=653$. Acesso em: 14 set. 2019.

SCHWADE, Elisete; WOORTMANN, Ellen Fensterseifer. Entrevista: Prof. Klaas Woortmann (UnB). Vivência: Revista de Antropologia, v.1, n.43, 16 mar. 2015. Disponível em: https://periodicos. ufrn.br/vivencia/article/view/6838. Acesso em: 17 jul. 2019.

SEGALEN, Martine. Sociología de la familia. Mar del Plata: Eudem, 2013.

SILVA, Cláudio Henrique Ribeiro da. Direito romano arcaico - I parte (sociedade e antecedentes culturais), s.d. Disponível em: http://www. ribeirodasilva.pro.br/direitoromanoarcaicoparte1-02.html. Acesso em: 18 jun. 2019.

SILVA, Mariana Cristina Lobato dos Santos Ribeiro et al. A abordagem à família na Estratégia Saúde da Família: uma revisão integrativa da literatura. Revista da Escola de Enfermagem da USP, v.45, n.5, p.1250-1255, 2011. Disponível em: www.ee.usp.br/reeusp. Acesso em: 20 jan. 2019.

SINGLY, François de. Sociologia da família contemporânea. Trad. Clarice Ehlers Peixoto. Rio de Janeiro: Editora FGV, 2007.

SINGLY, François de. O nascimento do "indivíduo individualizado" e seus efeitos na vida conjugal e familiar. In: Peixoto, Clarice Ehlers; Singly, François de; Cicchelli, Vincenzo (org.). Família e individualização. Trad. Angela Xavier de Brito. Rio de Janeiro: Editora FGV, 2000. p.13-19.

SOUZA, Heloísa M. Saúde da família: uma proposta que conquistou o Brasil. In: Brasil. Ministério da Saúde. Secretaria de Atenção à Saúde. Departamento de Atenção Básica. Memórias da saúde da família no Brasil. Brasília: Ministério da Saúde, 2010. p.31-35.

STRATHERN, Marilyn An. O efeito etnográfico e outros ensaios. São Paulo: Ubu Editora, 2017.

TELLES, Vera Silva. Direitos sociais: afinal do que se trata? Belo Horizonte: Editora UFMG, 2006.

TORRES, Anália Maria Cardoso. Sociologia da família: teorias e debates. Lisboa: Instituto
Universitário de Lisboa/Departamento de Sociologia/Relatório da Unidade Curricular, 2010.

TRAD, Leny A.B. (org). Família contemporânea e saúde: significados, práticas e políticas públicas. Rio de Janeiro: Editora Fiocruz, 2010.

TURTELLI, Camila; FERNANDES, Adriana; RODRIGUES, Eduardo. Ruralistas podem obter anistia de dívida de R 17 bilhões. Mudança no Projeto de Emenda da Reforma da Previdência pode abrir brecha para o perdão dos agricultores. O Estado de São Paulo, 18 jun. 2019. Disponível em: https://economia.estadao.com. br/noticias/geral,ruralistas-podem-obter-anistiade-divida-de-r-17-bilhoes,70002878018. Acesso em: 20 ago. 2019.

VERDÉLIO, Andréia. Mulheres trabalham 7,5 horas a mais que homens devido à dupla jornada: os dados estão no estudo Retrato das Desigualdades de gênero e raça. Agência Brasil, 6 mar. 2017. Disponível em: http://agenciabrasil. ebc.com.br/geral/noticia/2017-03/mulherestrabalham-75-horas-mais-que-homens-devidodupla-jornada. Acesso em: 15 jul. 2019.

VIANNA, Oliveira. Instituições políticas brasileiras. Belo Horizonte: Itatiaia; São Paulo: Editora da Universidade de São Paulo; Niterói: Editora da Universidade Federal Fluminense, 1987.

WALL, Karin; ABOIM, Sofia; CUNHA, Vanessa (coord.). A vida familiar no masculino: negociando velhas e novas masculinidades. Lisboa: Comissão para a igualdade no trabalho e no emprego, 2010.

WOORTMANN, Klaas. Lévi-Strauss e a família indesejada. Anuário Antropológico 2002-2003, v.28, n.1, p.291-350, 2003.

WOORTMANN, Klaas. A ideia de família em Malinowski. Campos, v.2, p.7-32, 2002.

WOORTMANN, Klaas. "Com parente não se neguceia": o campesinato como ordem moral. Anuário Antropológico, n.87, p.11-73, 1990.

WOORTMANN, Klaas. A família das mulheres. Rio de Janeiro: Tempo Brasileiro, 1987.

WOORTMANN, Klaas; WOORTMANN, Ellen. Monoparentalidade e chefia feminina: conceitos, contextos e circunstâncias. Brasília: Ed. UNB, 2004.

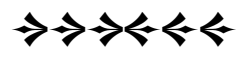

